\title{
ORIGINAL ARTICLE \\ Iron intake among Lebanese women: sociodemographic factors, iron-rich dietary patterns, and preparation of hummus, a Mediterranean dish
}

\author{
Nour Doumani',2,3*, Jacqueline Maalouly², Elias Bou-Maroun³, Nicolas Sok ${ }^{3}$, \\ Philippe Cayot ${ }^{3}$ and Maya Tueni' \\ 'Department of Biology, Nutrition \& Dietetics, Faculty of Sciences II, Lebanese University, Fanar, Lebanon; \\ ${ }^{2}$ Department of Chemistry \& Biochemistry, Faculty of Sciences II, Lebanese University, Fanar, Lebanon; ${ }^{3}$ UMR PAM \\ Food and Microbiological Processes, University of Burgundy Franche Comté/AgroSup Dijon, Dijon, France
}

\section{Popular scientific summary}

- Iron intake is still inadequate to dietary recommendations among Lebanese women from a nationally representative sample by age and region.

- Women with lower income are significantly more prone to have iron intake deficiency.

- Nonheme iron inhibitors are frequently consumed around mealtimes.

- Dietary pattern including hummus is related to higher intake of protein, vitamin C, and anemia-related nutrients.

- Less than the quarter of the women consider a proper preparation of hummus that enhances iron bioavailability.

Abstract

Background: Plant-based foods such as hummus are alternative to animal protein, and when properly prepared, they help to alleviate nutritional iron deficiency that leads to anemia, a global health problem.

Objective: The objective was to assess iron intake among Lebanese women and related participant's characteristics, discern iron-rich dietary patterns, evaluate their association with nutrients intake and participant's sociodemographic characteristics, and identify the women preparing hummus traditionally and properly for an enhanced iron bioavailability.

Design: A cross-sectional study of 400 Lebanese women (18-74 years old) was conducted in Lebanon. Data from a questionnaire, including sociodemographic and health characteristics, dietary intake, and hummus preparation and consumption, were collected. Dietary data were obtained by a food frequency questionnaire and a 24-h recall. Dietary patterns were identified by principal component analysis. Linear regression and binomial logistic regression models were used to explore the association between the intake of dietary iron, its patterns, and the participants' characteristics.

Results: About $60 \%$ of the women had iron intake deficiency, especially with lower income (odds ratio [OR] = $1.88,95 \%$ confidence interval $[\mathrm{CI}]: 1.107,3.194)$. Four iron-rich dietary patterns were identified: legumes; organ/lunch meat and chicken; canned fish; and beef and hummus. The factor scores of the latter were positively correlated with protein, vitamin $\mathrm{C}$, iron, folate, vitamin B12, and vitamin A with $r=0.195$ and $P<0.01$ for all. No significant difference was shown among the women's sociodemographic characteristics for the consumption of the hummus-related pattern. Only 9.2 and $22.7 \%$ of the women considered proper preparation of chickpea and hummus, respectively, which significantly $(P<0.05)$ correlated with older women $(66.7 \%)$.

Discussion \& Conclusion: The majority of the Lebanese women still have iron intake deficiency and the minority reported proper preparation of hummus. Intervention programs spreading awareness among Lebanese women are needed for encouraging adequate iron intake and considering proper steps to improve iron bioavailability from plant-based food.

Keywords: micronutrient intake deficiency; plant-based food; nonheme iron; Mediterranean and middle eastern countries; iron bioavailability 
I ron deficiency, accounting for $25 \%$ of anemia causes, is the most common nutritional disorder affecting people in developed as well as developing countries (1). This health condition is defined by an inadequate amount of iron and results in anemia. Women of reproductive age are at high risk of developing iron-deficiency anemia, especially in developing countries (2). In Lebanon, $16 \%$ of the childbearing-aged women have anemia and $27.2 \%$ have iron deficiency according to Al Khatib et al. (2006) (3); one major reason for developing them is attributed to the inadequate dietary intake of iron (4).

Two dietary sources of iron exist: animal and plant sources (5). Animal products such as meat poultry and fish contain heme iron, the form of iron easily absorbed by the human body. Although the consumption of animal-based products is important to provide the better form of dietary iron for absorption (heme iron), the climate researchers recommend a decrease of animal consumption since farming and livestock production are threatening to the environment and health (6-8). On the contrary, plant products such as legumes and pulses are eco-friendly, good for health (9-11), and have a high protein content. Legumes and pulses are good sources of iron. However, they contain the nonheme iron, which is the harder form of iron to be absorbed (12).

One famous traditional Lebanese dish based on legumes and consumed internationally is 'hummus', a spread made from mashed boiled chickpeas and blended with tahini, lemon juice, and garlic $(13,14)$. Hummus is not only an alternative to meat but also a dip that provides a good source of iron (2.4 mg of iron per $100 \mathrm{~g}$ hummus) (15). As the other plant-based products, the iron contained in hummus is poorly absorbed (nonheme iron). Nonheme iron assimilation is influenced by several factors such as the iron status and the gastric $\mathrm{pH}$ of the consumer, as well as dietary factors (16). The dietary factors include enhancers and inhibitors of iron bioavailability. On the one hand, some of these factors are endogenous to the food itself (17) and their content could be influenced through the processing and formulation of the same food (18-20). Regarding iron bioaccessibility from chickpea, soaking was shown to reduce antinutrients from chickpea (21-23). Cooking chickpea by a pressure cook was shown to be more effective in reducing the content of inhibitors than boiling $(18,24,25)$. One study showed that the decortication of chickpea reduced antinutrients and improved the bioavailability of iron (26). Regarding iron bioavailability from hummus, a recent study by Doumani and coworker (27) has shown that among all the steps for hummus preparation (soaking, bicarbonate addition, cooking, decortication of chickpea, lemon juice tahini, and garlic addition), only pressure cooking of chickpea, lemon juice, and tahini had a significant influence on its iron bioavailability. While pressure cooking and lemon juice addition were positively correlated with iron bioavailability, tahini addition was negatively correlated (27). On the other hand, some factors are exogenous to the food as they come from other items consumed concomitantly within the same meal $(28,29)$ and their interaction could be improved by making appropriate food combinations such as eating iron-rich food with vitamin-C-rich juices and avoiding polyphenol-rich food such as coffee. Therefore, food preparation (processing and formulation) and combination are important to consider as they influence iron bioavailability from plant-based food such as chickpea and hummus.

To the best of our knowledge, there is no study that investigated if the women are aware of proper preparation of plant-based food, particularly chickpea and hummus. Thus, this will be investigated in this study by conducting a survey on a sample of Lebanese women across all the Lebanese regions. Any sociodemographic characteristics association will be regarded as well. Our study targets the women as they are at high risk to develop iron deficiency and are still considered the prime source of cooking knowledge in Lebanese households and other countries too (30-32). The present study is divided into two sections. In the first section, the objectives are to 1) investigate iron intake among the Lebanese women and its relation with participants' characteristics and 2) distinguish the iron-rich dietary patterns and asses their association with nutrients intake and participant's sociodemographic characteristics. In the second section, the objective is to identify women who prepare hummus traditionally and investigate if women take into consideration the proper preparation of chickpea and hummus for an enhanced iron bioavailability.

\section{Materials and methods}

\section{Study design and sample}

A cross-sectional survey was carried out between May 2018 and October 2018, on a representative subpopulation of 400 women based on age and regions according to the Central Administration of Statistics of Lebanon in 2009 (33). The survey was a three-stage stratified, cluster sample that covered each of Lebanon's six administrative divisions (called governorates). The interviewees aged 18-74 years were randomly selected from the six governorates in Lebanon: Beirut, Mount Lebanon, North, Beqaa, South, and Nabatiyeh. The sample size for this study was calculated using the following formula: $n=\frac{N}{1+N(e)^{2}}$, where $n$ is the sample size, $N$ (1.9 million Lebanese women) is the population size, and $e$ is the level of precision at 5\% (34). Women were interviewed randomly in each region. From each household, one woman, young, middle aged, or old adult, was invited to participate 
in the survey. The exclusion criteria included pregnant or lactating women, and women with cognitive impairments and emotional problems. The participants were informed about the objectives of the survey and about their right to withdraw from the study at any time; $2 \%$ of the women dropped out from the study for a lack of time. The results were anonym and confidential. The study did not expose the participants to any risk.

\section{Data collection procedures}

The questionnaire was pretested on 30 women and then refined to further improve its validity and reliability. The questions were asked in Arabic-Lebanese (local language). Trained dietitians conducted face-to-face interviews and entered the data immediately through a computerized administration mode on their tablets. Each interview took an average of $20 \mathrm{~min}$. The questionnaire was divided into three parts: 1) sociodemographic and health characteristics, 2) dietary intake, and 3) hummus preparation and combination with food and beverage items for consumption.

\section{Sociodemographic characteristics}

The questionnaire covered information on sociodemographic characteristics, and it included six closeended questions: age (young: $18-39$ years, middle aged: 40-59 years, old adult: 60-74 years), residence area (rural or urban), marital status (married or not), university level (yes or no), work status (housewife or other, including working women and students), monthly family income $(\leq 500 \$$ or $>500 \$)$. Other characteristics such as body mass index (BMI), physical activity, and diet (normal or vegetarian) were covered as well. For the daily intake assessment part, women were classified into premenopausal (18-49 years) and menopausal women (50 years and more) respecting the recommended dietary requirements for each group. Weight and height were collected to calculate BMI as follows: $\mathrm{BMI}=\frac{\text { weight }(\mathrm{kg})}{\text { height }\left(\mathrm{m}^{2}\right)}(35)$. Concerning the physical activity, women were classified as sedentary or not active (doing no extra activity to independent living), or active including moderately active (doing extra activity equivalent to $2.5-5 \mathrm{~km}$ walking/day) and rigorously active (doing extra activity equivalent to more than $5 \mathrm{~km}$ walking/day) (36).

\section{Dietary intake}

The frequency of the consumption of iron-rich food and modulators of iron bioavailability was assessed by a qualitative food frequency questionnaire (FFQ) on monthly, weekly, or daily basis during the past 6 months with a total of 24 close-ended questions. The questionnaire included 17 food sources of iron divided into two categories according to the form of iron they contain. The first group included foods providing the heme and nonheme iron; these are exclusively from animal sources and included beef, organ meet, lunch meat, chicken, tuna, and sardines. The second group included foods providing solely nonheme iron; these originate from plants (except for the eggs) and covered beans, lentils, and chickpea presented as total legumes, hummus, green leafy vegetables, seeds, nuts, dried fruit, and carob molasses. The questionnaire also included seven modulators of iron bioavailability adapted from models in other Lebanese studies (37, 38). Iron enhancers included vitamin-C-rich fruit and juices (lemon and orange juices), whereas iron inhibitors included calcium, polyphenols, tannins, phytate, and/or fiber-rich food (milk, yogurt, coffee/tea, soft drinks, and whole wheat bread). The questionnaire was validated based on the 'Food-Based Dietary Guideline Manual for Promoting Healthy Eating in the Lebanese Adult Population: Lebanon' (37). As for the assessment of the daily intake of calories, iron, and nutrients influencing iron bioavailability (ascorbic acid, vitamin A, fibers, and calcium), a single 24-h dietary recall was employed. The 24-h dietary recall is an assessment tool of the type and quantity of food and beverage consumed in the past $24 \mathrm{~h}$ per a typical day of the week. The information obtained was analyzed by a nutritional software package 'Nutrilog 2018' (A French Nutrition Software Company) (38), and the nutrient intakes were calculated based on two food composition databases: The Middle Eastern food composition table for local dishes (39) and the United States Department of Agriculture (USDA) food composition table for international dishes (40).

\section{Distinction of iron-rich dietary patterns}

The principal component analysis (PCA) was used to identify iron-rich dietary patterns using the frequency dietary intake of 17 iron-rich food items. PCA is a data-driven method that reveals foods that are frequently consumed together by pooling food items on the basis of the degree to which they are correlated with one another (41). In this study, the PCA revealed the food items found to be frequently consumed together identified by the food frequency assessment. Before running the PCA procedure, the correlation matrix among the 17 iron-rich food groups was visually and statistically examined to justify undertaking the analysis. The Kaiser-Meyer-Olkin measure of sampling adequacy test had a score of 0.656 $(>0.6)$, and the $\chi^{2}$ for the Bartlett test of sphericity was significant as the $P$-value was less than 0.05 , indicating that the correlation among the variables was sufficiently strong for a PCA. The number of components (factors) was retained based on three criteria: 1) the Kaiser criterion (eigenvalues $>1$ ); 2 ) inflection point of the scree plot; and 3) interpretability of factors (42). To achieve a simple structure with greater interpretability, the factors were rotated using an orthogonal transformation known 
as Varimax rotation (41). Factor loadings indicated the strength and direction of the relationship between the food items and each dietary pattern. These were labeled on the basis of the iron-rich food items having a rotated factor loading $>0.5$. The multiple regression approach was used to calculate the factor scores. Each participant received a factor score for each iron-rich dietary pattern, showing the degree to which each individual's iron food consumption corresponded to the identified pattern.

\section{Hummus preparation and consumption}

The 12 questions related to hummus preparation and consumption with food and beverage included hummus preparation traditionally (from raw ingredients), not traditionally (from industrially cooked chickpeas), or neither of these (do not prepare hummus). For the traditional preparation, further questions were addressed, including precooking of chickpeas (soaking, with bicarbonate, discarding the water), cooking (boiling or pressure cooking), and post-cooking (decortication of chickpea). For all the women who reported to prepare hummus, they were asked about the proportions of ingredients used for making hummus (tahini, garlic, and lemon juice). All the women were asked about their preferences for food and beverages items combined with hummus consumption (meat or vegetables, refined or unrefined bread, and soft drinks or yogurt or vitamin-C-rich juices).

\section{Proper chickpea and hummus preparation}

To evaluate if women properly prepare chickpea and hummus, we have considered the processing and formulation steps that have been proved in the literature $(18,24,25,27)$ to improve iron bioaccessibility and bioavailability from chickpea and hummus, respectively. Regarding chickpea, three steps were considered: soaking chickpea, cooking chickpea with a pressure cook, and decortication of chickpea. Regarding hummus, three steps were considered: pressure cooking, more lemon juice addition, and less tahini.

\section{Statistical analysis}

Descriptive statistics were calculated and results are expressed as mean values \pm standard deviations (SD) for continuous variables and percentages for categorical variables. As the energy-adjusted nutrient intakes were not normally distributed, they were presented as quartiles. To study the relationship between categorical variables, the $\chi^{2}$-test was used. Dietary consumption of macroand micronutrients was analyzed using professional nutritional software NutriLog 3.01 (38). A multiple linear regression was used to assess the association between the normalized total iron intake (dependent continuous variable) and the participants' sociodemographic characteristics (independent categorical variables), as well as between the normalized iron intake adequacy percentage (dependent continuous variable) and the participants' sociodemographic characteristics (independent categorical variables). A binomial logistic regression analysis was conducted in order to assess the role of the participants' sociodemographic characteristics (predictors) on the iron intake deficiency (dichotomous outcome). The odds ratios (ORs) and their 95\% confidence intervals (CIs) for each of the variables were generated. To study the association between iron-rich dietary patterns and the nutrient intake, Spearman's rank correlation coefficients with two-sided significance levels were calculated between the factor scores of each pattern and the energy-adjusted nutrient intakes. This nonparametric test was used as both continuous variables (factor scores and energy-adjusted nutrient intakes) were not normally distributed. To study the association between the factor scores of the iron-rich dietary patterns (continuous, dependent variables) and the sociodemographic characteristics (dichotomous, independent variables), a multiple linear regression analysis was applied to assess their associations. For all the linear regressions, the assumptions were fulfilled to assess the validity of the final regression models including the residual analysis and collinearity diagnosis. The Statistical Package for the Social Sciences version 21.0 (SPSS for Windows; SPSS Inc., Chicago, IL, USA) was used. A $P$-value less than 0.05 was considered significant.

\section{Results}

\section{Descriptive characteristics of the sample}

The socio-demographic and health characteristics of the sample are described in Table 1. Out of the 400 study participants, slightly more than the half were young adults $(56 \%)$, from urban areas $(54 \%)$, hold a higher academic degree $(52 \%)$, and with busy lifestyles $(65 \%)$. Concerning health characteristics of the women, the overall means for the weight and height were $66.79 \pm 11.3 \mathrm{~kg}$ and $1.64 \pm 0.003 \mathrm{~m}$, respectively. The average BMI was $24.95 \pm 0.21 \mathrm{~kg} / \mathrm{m}^{2}$, and about half the women had a BMI of $<25 \mathrm{~kg} / \mathrm{m}^{2}(53.25 \%)$ with almost all of them $(93 \%)$ having a normal BMI. Furthermore, slightly more than half the women had a moderate or vigorous activity $(54.75 \%)$ and almost all of them followed a normal diet.

\section{Iron intake data}

Consumption frequency of iron rich food based on FFQ The percentages of the participants consuming iron-rich products are shown in Table 2. Our study shows that beef and chicken are the primary sources of heme iron intake as more than $90 \%$ of the women reported their consumption frequently (at least once a week). Concerning the nonheme iron intake, hummus like legumes and green leafy vegetables constitutes a major source of the nonheme iron as at least $80 \%$ of the women reported its 
Table 1. Descriptive socio-demographic and health characteristics of the studied sample $(N=400)$, Lebanon 2018

\begin{tabular}{|c|c|c|c|c|c|}
\hline \multirow[t]{2}{*}{ Characteristic } & Frequency & Percentage & Characteristic & Frequency & Percentage \\
\hline & $n$ & $\%$ & & $n$ & $\%$ \\
\hline Age group ${ }^{a}$ & & & Monthly total income & & \\
\hline Young adult & 224 & 56.0 & $\leq 500 \$$ & 120 & 30.0 \\
\hline Middle-aged/old adults & 176 & 44.0 & $>500 \$$ & 280 & 70.0 \\
\hline Residence area & & & BMIc & & \\
\hline Rural & 184 & 45.9 & $<25 \mathrm{~kg} / \mathrm{m}^{2}$ & 213 & 53.25 \\
\hline Urban & 216 & 54.1 & $\geq 25 \mathrm{~kg} / \mathrm{m}^{2}$ & 187 & 46.75 \\
\hline Marital status & & & Physical activity ${ }^{d}$ & & \\
\hline Never married & 168 & 42.0 & Not active & $|8|$ & 45.25 \\
\hline Married & 232 & 58.0 & Active & 219 & 54.75 \\
\hline University level & & & Diet & & \\
\hline No & 190 & 47.5 & Vegetarian & 7 & 1.8 \\
\hline Yes & 210 & 52.5 & Normal & 393 & 98.2 \\
\hline \multicolumn{6}{|l|}{ Occupational status ${ }^{b}$} \\
\hline Housewife & $|4|$ & 35.2 & & & \\
\hline Other & 259 & 64.8 & & & \\
\hline
\end{tabular}

aYoung adult: aged 18-39 years old; middle aged: 39-59 years old; old adults: 60-74 years old.

'Occupational status: other means working women and students.

${ }^{\mathrm{C}} \mathrm{BMI}$ is the body mass index and is obtained by dividing the weight $(\mathrm{kg})$ by height square $(\mathrm{m})$. It is divided into two categories: underweight $\left(<18.5 \mathrm{~kg} / \mathrm{m}^{2}\right)$ and normal $\left(18.5-24.9 \mathrm{~kg} / \mathrm{m}^{2}\right)$ which are $<25 \mathrm{~kg} / \mathrm{m}^{2}$ and another category which are $>25 \mathrm{~kg} / \mathrm{m}^{2}$ including overweight $\left(25-29.9 \mathrm{~kg} / \mathrm{m}^{2}\right)$ and obese $\left(\geq 30 \mathrm{~kg} / \mathrm{m}^{2}\right)(35)$.

dPhysical activity: not active includes the sedentary women with no extra activity, and active includes the women who do an activity (moderate or intense) equivalent to at least $2-5 \mathrm{~km}$ walking/day (36).

Table 2. Frequency of consumption of iron-rich food, iron enhancers, and iron inhibitors reported by the total study population of the Lebanese women aged $18-74$ years $(N=400)$ and expressed in \% of consumers, Lebanon 2018

\begin{tabular}{|c|c|c|c|c|c|c|}
\hline \multirow[t]{2}{*}{ Food item } & & \multicolumn{5}{|c|}{$\begin{array}{l}\text { \% of consumers } \\
\text { Frequency of consumption }\end{array}$} \\
\hline & & \multirow[t]{2}{*}{ Monthly } & \multicolumn{2}{|c|}{$\begin{array}{l}\text { Weekly } \\
\text { I-2 ... 3-6 }\end{array}$} & \multirow[t]{2}{*}{ Daily } & $P$ \\
\hline Iron-rich food in both forms & Iron content $(\mathrm{mg}) /$ serving) ${ }^{\mathrm{a}}$ & & & & & $0.038 *$ \\
\hline Heme and nonheme iron ${ }^{b}$ & $40 \%$ heme $(\mathrm{H})$ vs. $60 \%$ nonheme $(\mathrm{NH})$ & 42.6 & 26.0 & 30.1 & 1.2 & \\
\hline Beef, tenderloin, and cooked ( $90 \mathrm{~g}$ ) & 3 & 9.2 & 23.5 & 64.6 & 2.7 & \\
\hline Organ meat (90 g) & $5.2-9.9$ & 76.0 & 20.2 & 3.2 & 0.6 & \\
\hline Lunch meat ( $100 \mathrm{~g})$ & 1.9 & 43.8 & 28.5 & 25.4 & 2.3 & \\
\hline Chicken (I00 g) & 1.1 & 4.8 & 21.8 & 72.2 & 1.2 & \\
\hline Tuna (I can) & 2.5 & 44.8 & 43.0 & 12.0 & 0.2 & \\
\hline Sardines (I can) & 2.5 & 77.2 & 19.2 & 3.4 & 0.2 & \\
\hline Only nonheme iron ${ }^{c}$ & $100 \% \mathrm{NH}$ & 34.1 & 33.6 & 24.5 & 7.8 & \\
\hline Egg (I large of $50 \mathrm{~g})$ & 0.6 & 24.5 & 47.2 & 25.8 & 2.5 & \\
\hline Breakfast cereal fortified $(3 / 4$ cup $)$ & 4.5 & 63.0 & 16.5 & 17.8 & 2.7 & \\
\hline Total legumes cooked (I cup $)^{d}$ & 5.5 & 15.7 & 32.3 & 47.5 & 4.5 & \\
\hline Hummus (100 g) & 2.4 & 19.2 & 58.8 & 22 & 0.0 & \\
\hline Green leafy vegetables $(I \text { cup })^{e}$ & 0.4 & 12.4 & 21.8 & 28 & 37.8 & \\
\hline Dried fruit $(1 / 4 \text { cup })^{f}$ & 0.8 & 57.5 & 25.0 & 13.5 & 4.0 & \\
\hline Roasted pumpkin seeds ( $1 / 4$ cup) & I.4-4.7 & 47.0 & 28.8 & 18.7 & 5.5 & \\
\hline Nuts $(1 / 4$ cup $)$ & $1.3-2.2$ & 33.8 & 38.5 & 22.3 & 5.4 & \\
\hline Carob molasses (I tablespoon) & 3.5 & 84.2 & 11.0 & 3.7 & I.I & \\
\hline
\end{tabular}


Table 2. Continued

\begin{tabular}{|c|c|c|c|c|c|}
\hline \multirow[t]{2}{*}{ Food item } & & \multicolumn{4}{|c|}{$\begin{array}{l}\% \text { of consumers } \\
\text { Frequency of consumption }\end{array}$} \\
\hline & & \multirow[t]{2}{*}{ Monthly } & \multirow[t]{2}{*}{$\begin{array}{c}\text { Weekly } \\
\text { I-2 ... 3-6 }\end{array}$} & Daily & $P$ \\
\hline $\begin{array}{l}\text { Iron-enhancing or iro } \\
\text { around mealtimes }\end{array}$ & & & & & $0.010 *$ \\
\hline Iron enhancers ${ }^{\mathrm{g}, \mathrm{h}}$ & & 52.3 & 42.9 & 4.8 & \\
\hline Lemon/orange juice & - & 55.2 & 40.0 & 4.2 & \\
\hline Citrus fruit & & 48.8 & 45.7 & 5.5 & \\
\hline Iron inhibitors ${ }^{\mathrm{g}, \mathrm{i}}$ & & 36.9 & 46.1 & 17.0 & \\
\hline Milk & - & 55.2 & 37.6 & 7.2 & \\
\hline Yogurt & - & 21.0 & 71 & 8.0 & \\
\hline Coffee or tea & - & 23.7 & 36.3 & 40.0 & \\
\hline Soft drinks with caffeine & - & 40.2 & 49.6 & 10.2 & \\
\hline Whole wheat bread & - & 44.5 & 36.0 & 19.5 & \\
\hline
\end{tabular}

aReferences: $(14,15,38)$.

${ }^{b}$ Animal sources, except eggs, are assumed to contain $40 \%$ heme iron and $60 \%$ nonheme iron (43).

'Plant sources, in addition to eggs, contain 100\% nonheme iron.

Iron content in legumes is the mean iron content from chickpea, lentils, and beans (commonly consumed legumes).

eIron content in green leafy vegetables is the mean iron content from raw: arugula, chicory, chard, kale, romaine lettuce, and spinach (commonly consumed leafy vegetables).

fIron content in dried fruits is the mean iron content from dates, dried apricots, and dried raisins (commonly consumed dried fruits).

glron absorption modulators consumed around meal times (i.e. breakfast, lunch, and dinner).

hThe percentage of women consuming iron enhancers is the mean percentage of the women consuming lemon/orange juice and citrus fruit.

'The percentage of women consuming iron inhibitors is the mean percentage of the women consuming milk, yogurt, coffee/tea, soft drinks, and whole wheat bread.

*Significance level set at $p$-value $<0.05$

frequent consumption (at least once a week). Frequency of heme iron intake in our panel is considerable (57.3\% with $P=0.038)$, but it is less important than the frequency of the nonheme iron intake (65.9\% with $P=0.038)$. Thus, the consumption of nonheme iron bioavailability modulators around mealtimes is investigated.

\section{Consumption frequency of dietary modulators of nonheme} iron bioavailability based on FFQ

The percentages of the participants consuming ironenhancing and iron-inhibiting food items around mealtimes are shown in Table 2. There is a significantly higher percentage of the participants consuming frequently iron inhibitors around mealtimes than the percentage of participants consuming frequently iron enhancers $(63.1 \%$ vs. $47.7 \%$ with $P=0.010$ ). This means that nonheme ironrich food generally consumed during the meals must be more prone to interact with inhibitors of iron bioavailability (e.g., polyphenols, tannins, and calcium) instead of enhancers (e.g., vitamin C).

Dietary intake for iron and other anemia-related nutrients based on 24-h recall

The mean intake, mean intake adequacy, and percentage of women with dietary intake deficiency for energy-adjusted nutrients are shown in Table 3. The mean intake adequacy percentage for iron is considerably lower among women of childbearing age $(65.58 \%$ of recommended dietary allowance [RDA]) than postmenopausal women $(142.77 \%$ of RDA) but is almost similar for other anemia-related nutrients: folate $(59.6 \%$ of $\mathrm{RDA})$, vitamin B12 $(125.9 \%$ of RDA), and vitamin A ( $56 \%$ of RDA), as well as ascorbic acid ( $82.6 \%$ of RDA). About $60 \%$ of the childbearing-aged women have iron intake deficiency, and more than $70 \%$ of them have intake deficiencies for folate (70.6\%) and vitamin A (81.6\%).

A 24-h recall was used to estimate the intake in terms of nutrients by using the NutriLog software.

Dietary iron intake and population characteristics

A multiple regression was run to predict total iron intake and iron intake adequacy from sociodemographic characteristics of the study participants (Table 4). Monthly total income was significantly positively associated with total iron intake ( $\beta=0.18,95 \%$ CI: $0.58,1.97)$ and iron intake adequacy $\%$ ( $\beta=0.12,95 \%$ CI: $4.39,16.2)$. Total iron intake was significantly positively associated with the education level ( $\beta=0.14,95 \%$ CI: $0.13,1.74)$, and iron intake adequacy (\%) was significantly positively associated with age ( $\beta=0.75,95 \%$ CI: $62.48,76.68)$. The iron intake deficiency and its association with the sociodemographic characteristics are also investigated. 
Table 3. Recommended dietary allowance (RDA), daily intake as quartiles and mean values, mean intake adequacy, and percentage of women with dietary intake deficiency for selected nutrients $(N=400)$, Lebanon 2018

\begin{tabular}{|c|c|c|c|c|c|c|c|}
\hline \multirow[t]{2}{*}{ Nutrient ${ }^{\mathrm{a}}$} & \multicolumn{5}{|c|}{ Nutrient intake represented in quartiles and mean values } & \multirow{2}{*}{$\begin{array}{l}\text { Mean intake adequacy } \\
\qquad \% \pm S D\end{array}$} & \multirow{2}{*}{$\begin{array}{l}\% \text { of women with } \\
\text { intake deficiency }\end{array}$} \\
\hline & RDA $^{b}$ & QI & Q2 & Q3 & $\begin{array}{c}\text { Mean } \pm \text { standard } \\
\text { deviation (SD) }\end{array}$ & & \\
\hline \multicolumn{8}{|c|}{ Total iron (mg) } \\
\hline & $18^{c}$ & 9.67 & 11.33 & $|3.5|$ & $11.80 \pm 3.56$ & $65.58 \pm 19.77$ & 58.50 \\
\hline & $8^{d}$ & 9.44 & 11.22 & 13.07 & $11.42 \pm 2.45$ & $142.77 \pm 30.64$ & 1.00 \\
\hline \multicolumn{8}{|c|}{ Ascorbic acid (mg) } \\
\hline & $75^{c}$ & 54.46 & 60.85 & 69.40 & $62.72 \pm 14.38$ & $83.63 \pm 19.18$ & 10.70 \\
\hline & $75^{d}$ & 53.37 & 60.24 & 67.51 & $61.18 \pm 9.62$ & $81.58 \pm 12.82$ & 9.00 \\
\hline \multicolumn{8}{|l|}{ Folate $(\mu g)$} \\
\hline & $400^{c}$ & 196.68 & 232.79 & 279.55 & $242.51 \pm 75.65$ & $60.63 \pm 18.91$ & 70.60 \\
\hline & $400^{d}$ & 191.82 & 230.25 & 270.20 & $234.33 \pm 53.02$ & $58.58 \pm 13.25$ & 73.00 \\
\hline \multicolumn{8}{|c|}{ Vitamin $B \mid 2(\mu \mathrm{g})$} \\
\hline & $2.4^{c}$ & 2.20 & 2.92 & 3.85 & $3.09 \pm 1.33$ & $128.82 \pm 55.49$ & 8.00 \\
\hline & $2.4^{\mathrm{d}}$ & 2.10 & 2.87 & 3.66 & $2.95 \pm 1.05$ & $123.06 \pm 43.95$ & 4.00 \\
\hline \multicolumn{8}{|c|}{ Vitamin A $(\mu g)$} \\
\hline & $700^{c}$ & 336.75 & 385.73 & 450.52 & $397.30 \pm 90.47$ & $56.76 \pm 12.92$ & 81.60 \\
\hline & $700^{d}$ & 329.00 & 382.16 & 436.75 & $387.66 \pm 71.66$ & $55.38 \pm 10.24$ & 87.00 \\
\hline
\end{tabular}

aThe nutrients are energy-adjusted using the method of residuals (44).

bRDA - recommended dietary allowance: mean daily intake level sufficient to meet the nutrient requirements of healthy individuals (45).

cMean RDA values for women aged between 18 and 49 years $(n=300)$.

Mean RDA values for women aged 50 years and more $(n=100)$.

ePercentage of women consuming less than 2/3 RDA values for a certain nutrient.

Table 4. Association of baseline sociodemographic characteristics with the normalized total iron intake and the iron intake adequacy $\%$ in the study population as assessed by multiple linear regression

\begin{tabular}{|c|c|c|c|c|c|c|}
\hline \multirow{3}{*}{$\begin{array}{l}\text { Characteristics }^{\mathrm{a}} \\
\text { (constant) }\end{array}$} & \multicolumn{3}{|c|}{ Total iron intake } & \multicolumn{3}{|c|}{ Iron intake adequacy (\%) } \\
\hline & \multirow[t]{2}{*}{$\beta$} & \multicolumn{2}{|c|}{$95 \%$ confidence interval $(\mathrm{Cl})$} & \multirow[t]{2}{*}{$\beta$} & \multicolumn{2}{|c|}{$95 \% \mathrm{Cl}$} \\
\hline & & 4.84 & 10.87 & & -52.94 & -0.18 \\
\hline Age & 0.08 & -0.24 & 1.35 & $0.75^{*}$ & 62.48 & 76.68 \\
\hline Residence area & 0.03 & -0.47 & 0.82 & 0.02 & -4.23 & 6.79 \\
\hline Marital status & -0.02 & -0.96 & 0.63 & 0.00 & -6.40 & 6.75 \\
\hline University degree & $0.14 *$ & 0.13 & 1.74 & 0.08 & -0.41 & $|3.3|$ \\
\hline Occupational status & -0.05 & -1.19 & 0.52 & -0.04 & -10.36 & 4.10 \\
\hline Monthly total income & $0.18^{*}$ & 0.58 & 1.97 & $0.12 *$ & 4.39 & 16.20 \\
\hline
\end{tabular}

$* \beta$ and $95 \% \mathrm{Cl}$ are significant at $P<0.05$.

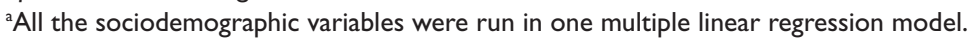

Table 5 illustrates the binomial logistic regression between the iron intake deficiency (dependent variable) and the sociodemographic characteristics factors (independent variables). From the variables, only age and monthly total income added significantly to the model. The odds of having iron intake deficiency is clearly more likely among premenopausal women than postmenopausal women $(\mathrm{OR}=171.429,95 \%$ CI: 23.0, 1277.65). Women with lower monthly total income are approximately two times more likely $(\mathrm{OR}=1.88$,
$95 \%$ CI: $1.107,3.194)$ to have iron intake deficiency than women with higher income.

Iron-rich dietary patterns

Identification of the iron-rich dietary patterns

Four iron-rich dietary patterns were obtained from the PCA, which collectively explained $38.4 \%$ of the variance in the frequency of dietary intake. Table 6 shows the factor loadings of the four patterns named according to the 
Table 5. Binomial logistic regression between iron intake deficiency and sociodemographic characteristics

\begin{tabular}{|c|c|c|c|}
\hline \multirow[t]{2}{*}{ Characteristics } & \multicolumn{3}{|c|}{ Iron intake deficiency } \\
\hline & Odd ratio & $95 \%$ confid & e interval $(\mathrm{Cl})$ \\
\hline Constant & $0.007^{*}$ & & \\
\hline \multicolumn{4}{|l|}{ Age group $^{\mathrm{a}}$} \\
\hline Young adult & $171.429 *$ & 23.001 & 1277.646 \\
\hline Middle-aged/old adults (rc) & I & & \\
\hline \multicolumn{4}{|l|}{ Residence area } \\
\hline Rural & 1.051 & 0.653 & 1.689 \\
\hline Urban (rc) & $\mathrm{I}$ & & \\
\hline \multicolumn{4}{|l|}{ Marital status } \\
\hline Never married & 0.795 & 0.449 & 1.409 \\
\hline Married (rc) & 1 & & \\
\hline \multicolumn{4}{|l|}{ University level } \\
\hline No & 1.220 & 0.683 & 2.180 \\
\hline Yes (rc) & $\mathrm{I}$ & & \\
\hline \multicolumn{4}{|l|}{ Occupational status ${ }^{b}$} \\
\hline Housewife & 0.847 & 0.432 & $\mathrm{I} .66 \mathrm{I}$ \\
\hline Other (rc) & I & & \\
\hline \multicolumn{4}{|l|}{ Monthly total income } \\
\hline$\leq 500 \$$ & $1.880 *$ & 1.107 & 3.194 \\
\hline$>500 \$(\mathrm{rc})$ & I & & \\
\hline
\end{tabular}

aYoung adult: aged 18-39 years old; middle aged: 39-59 years old; old adults: $60-74$ years old.

'Occupational status: other means working women and students. Rc: reference category in the binomial logistic regression.

*Significance level set at $p$-value $<0.05$. iron-rich food items loading highest on the respective iron-rich dietary pattern. Therefore, the patterns obtained were classified as follows: 'legume' pattern, which was positively associated with high-frequency consumption of beans, lentils, and chickpea; the 'organ/Lunch meat and chicken' pattern, as its name depicts, characterized by a high consumption of organ meat, lunch meat, and chicken; the 'canned fish' pattern, which was positively associated with high-frequency consumption of tuna and sardines; and the 'beef and hummus' pattern, as its name depicts, characterized by a high consumption of beef and hummus.

Iron-rich dietary patterns and nutrients intake

Table 7 presents the associations of the factor scores of the various iron-rich dietary patterns with energy-adjusted nutrient intakes related to anemia. Among the four ironrich dietary patterns, only the scores of the beef and hummus pattern had a significant and positive association with all the nutrients: protein $(r=0.195, P<0.01)$, ascorbic acid $(r=0.193, P<0.01)$, iron $(r=0.193, P<0.01)$, folate $(r=0.192, P<0.01)$, vitamin B12 $(r=0.194, P<0.01)$ and vitamin A $(r=0.192, P<0.01)$.

\section{Iron-rich dietary patterns and sociodemographic} characteristics

Table 8 illustrates the association between the four ironrich dietary patterns and the sociodemographic characteristics of the study participants. Almost none of the

Table 6. Factor loading matrix for the four patterns of iron food source identified in the study population $(N=400)$, Lebanon 2018

\begin{tabular}{|c|c|c|c|c|}
\hline \multirow[t]{2}{*}{ Iron-rich food items } & \multicolumn{4}{|c|}{ Iron-rich dietary pattern } \\
\hline & Legumes & Organ/lunch meat and chicken & Canned fish & Beef and hummus \\
\hline Beef, tenderloin, and cooked & & & & 0.712 \\
\hline Organ meat & & 0.631 & & \\
\hline Lunch meat & & 0.597 & & \\
\hline Chicken & & 0.591 & & \\
\hline Tuna & & & 0.594 & \\
\hline Sardines & & & 0.765 & \\
\hline \multicolumn{5}{|l|}{ Egg } \\
\hline \multicolumn{5}{|l|}{ Breakfast cereal fortified } \\
\hline Beans & 0.837 & & & \\
\hline Lentils & 0.807 & & & \\
\hline Chickpea & 0.665 & & & \\
\hline Hummus & & & & 0.582 \\
\hline \multicolumn{5}{|l|}{ Green leafy vegetables } \\
\hline \multicolumn{5}{|l|}{ Dried fruit } \\
\hline \multicolumn{5}{|l|}{ Roasted pumpkin seeds } \\
\hline \multicolumn{5}{|l|}{ Nuts } \\
\hline Carob molasses & & & & \\
\hline
\end{tabular}

Rotation method: varimax with Kaiser normalization.

Kaiser-Meyer-Olkin measure of sampling adequacy $=0.656$.

Bartlett's test of sphericity $<0.05$ and $<0.0$ I.

Factor loadings represented are values $>0.5$. 
Table 7. Spearman's correlation between the factor scores of the four iron-rich food patterns and the energy-adjusted nutrients intake related to iron deficiency and anemia

\begin{tabular}{|c|c|c|c|c|}
\hline Nutrient $^{\mathrm{a}}$ & Legumes & Organ/lunch meat and chicken & Canned fish & Beef and hummus \\
\hline Iron & 0.077 & -0.084 & -0.074 & $0.193 * *$ \\
\hline Heme iron & 0.075 & -0.086 & -0.074 & $0.195^{* *}$ \\
\hline Nonheme iron & 0.077 & -0.084 & -0.074 & $0.193 * *$ \\
\hline Protein & 0.077 & -0.085 & -0.074 & $0.195 * *$ \\
\hline Ascorbic acid & 0.080 & -0.087 & -0.074 & $0.193^{* *}$ \\
\hline Folate & 0.077 & -0.086 & -0.075 & $0.193 * *$ \\
\hline Vitamin $\mathrm{B} / 2$ & 0.075 & -0.086 & -0.074 & $0.194 * *$ \\
\hline Vitamin A & 0.076 & -0.084 & -0.074 & $0.192^{* *}$ \\
\hline
\end{tabular}

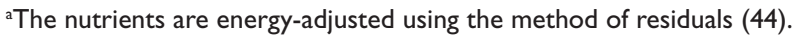

**Correlation is significant at the 0.01 level (two tailed).

Table 8. Association between the factor scores of the four iron-rich dietary patterns and the sociodemographic characteristics by a multiple linear regression

\begin{tabular}{|c|c|c|c|c|c|c|c|c|c|c|c|c|}
\hline \multirow{3}{*}{$\begin{array}{l}\text { Characteristics }^{\mathrm{a}} \\
\text { Constant }\end{array}$} & \multicolumn{3}{|c|}{ Legumes } & \multicolumn{3}{|c|}{ Organ/lunch meat and chicken } & \multicolumn{3}{|c|}{ Canned fish } & \multicolumn{3}{|c|}{ Beef and hummus } \\
\hline & \multirow[t]{2}{*}{$\beta$} & \multicolumn{2}{|c|}{$\begin{array}{l}95 \% \text { confidence } \\
\text { interval }(\mathrm{Cl})\end{array}$} & \multirow[t]{2}{*}{$\beta$} & \multicolumn{2}{|c|}{$95 \% \mathrm{Cl}$} & \multirow[t]{2}{*}{$\beta$} & \multicolumn{2}{|c|}{$95 \% \mathrm{Cl}$} & \multirow[t]{2}{*}{$\beta$} & \multicolumn{2}{|c|}{$95 \% \mathrm{Cl}$} \\
\hline & & -1.086 & 0.772 & & -0.599 & 1.279 & & -2.476 & 1.943 & & -1.007 & 0.85 \\
\hline Age & 0.067 & -0.116 & 0.382 & -0.004 & -0.261 & 0.243 & 0.246 & -0.136 & 1.208 & 0.098 & -0.055 & 0.443 \\
\hline Residence area & 0.011 & -0.182 & 0.224 & 0.046 & -0.112 & 0.298 & 0.077 & -0.364 & 0.701 & 0.066 & -0.073 & 0.333 \\
\hline Marital status & -0.028 & -0.305 & 0.194 & 0.017 & -0.218 & 0.286 & -0.100 & -0.900 & 0.457 & -0.040 & -0.329 & 0.168 \\
\hline $\begin{array}{l}\text { University } \\
\text { degree }\end{array}$ & 0.058 & -0.138 & 0.365 & -0.103 & $-0.46 I$ & 0.048 & 0.006 & -0.639 & 0.667 & -0.030 & -0.312 & 0.191 \\
\hline $\begin{array}{l}\text { Occupational } \\
\text { status }\end{array}$ & 0.048 & -0.169 & 0.365 & 0.007 & -0.255 & 0.284 & 0.111 & -0.429 & 0.936 & 0.009 & -0.248 & 0.28 \\
\hline $\begin{array}{l}\text { Monthly total } \\
\text { income }\end{array}$ & -0.085 & -0.402 & 0.034 & -0.063 & -0.359 & 0.082 & $-0.268^{*}$ & -1.215 & -0.065 & -0.059 & -0.345 & 0.092 \\
\hline
\end{tabular}

${ }^{a}$ All the sociodemographic variables were run in one multiple linear regression model.

$* \beta$ and $95 \% \mathrm{Cl}$ are significant at $P<0.05$.

variables was predictive for any of the iron-rich pattern except the monthly total income. A significant association was seen between the frequent consumption of canned fish and the participants with lower monthly income $(\beta=-0.268,95 \%$ CI: $-1.215,-0.065)$.

\section{Hummus preparation and consumption}

\section{Common steps for hummus preparation and combination preferences with food}

The preparation and the habitual food and beverage intake with hummus are reported in Fig. 1. Concerning the preparation methods, 1) soaking and discarding the soaking water are commonly practiced among the women ( 98 and $89 \%$, respectively) and 2) addition of bicarbonate to soaking water is practiced by slightly less than the half $(45 \%)$. The majority of the women cook using a regular pot $(59 \%)$ and few of them decorticate chickpea $(15 \%)$. Lemon juice and tahini are the principal ingredients added to chickpea puree. Garlic is also added by the majority $(83 \%)$. Meat, an iron assimilation enhancer and a good source of iron as well $(71,72)$, is consumed with hummus by the majority of the women $(69 \%)$. Almost all of the women $(90 \%)$ prefer to consume pita bread (refined bread) with hummus more than the whole wheat bread. Pita bread may be a better option than whole wheat bread for its lower content in phytate (46). Soft drinks which are also consumed with hummus by the majority of the women $(76 \%)$ are considered inhibitors of iron assimilation as food components in these beverages (e.g., polyphenols and caffeine...) may decrease the absorption of iron in food (37).

Women who prepare hummus traditionally

The sociodemographic characteristics related to hummus preparation are shown in Table 9. More than three quarter $(77.7 \%)$ of women prepare hummus, including mainly housewives and married women (93 and 88\%, 


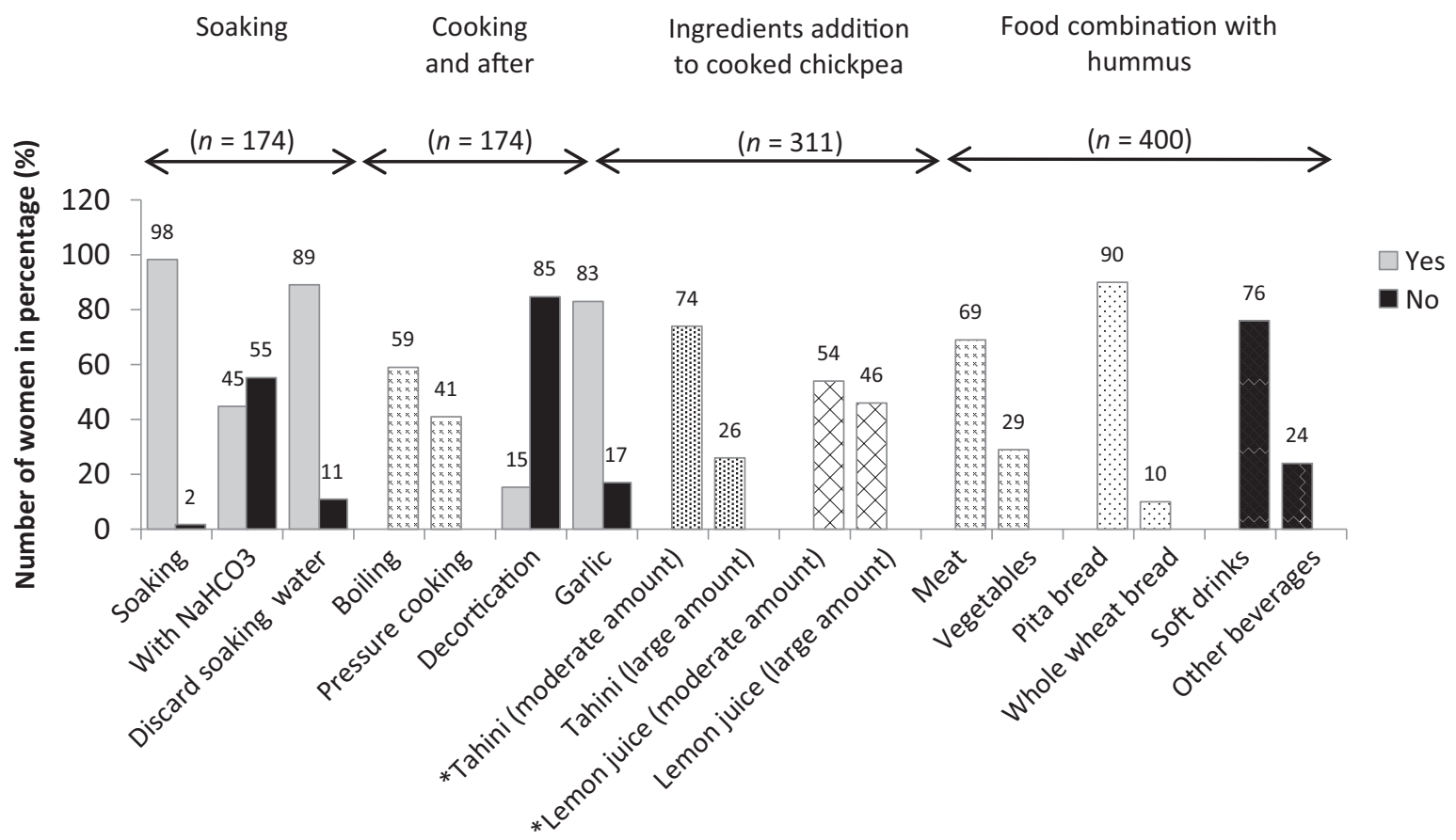

Fig. 1. Preparation of hummus and combination with food and beverage among the studied sample $(N=400)$, Lebanon 2018 . Soaking and cooking steps are reported by the women who prepare hummus traditionally $(n=174)$. Ingredient addition is reported by all the women who prepare hummus $(\mathrm{n}=311)$. Food combination with hummus for consumption is reported by all the women $(N=400)$.

*The amounts of tahini and lemon juice are evaluated in comparison with a traditional Lebanese recipe of hummus (47).

Table 9. The Lebanese women who prepare hummus traditionally or not, according to the socioeconomic and demographic characteristics $(N=400)$, Lebanon 2018

\begin{tabular}{|c|c|c|c|c|c|c|c|}
\hline \multirow[t]{4}{*}{ Characteristic } & \multicolumn{4}{|c|}{ Prepare hummus } & \multirow{2}{*}{\multicolumn{2}{|c|}{$\begin{array}{c}\text { Do not prepare hummus } \\
\qquad n=89(22.3 \%)\end{array}$}} & \multirow[t]{4}{*}{$P$} \\
\hline & \multicolumn{4}{|c|}{$n=311(77.7 \%)$} & & & \\
\hline & \multicolumn{2}{|c|}{ Traditionally } & \multicolumn{2}{|c|}{ Not traditionally } & & & \\
\hline & $n$ & $\%$ & $n$ & $\%$ & $n$ & $\%$ & \\
\hline Age group $^{a}$ & & & & & & & $0.015^{*}$ \\
\hline Young adult & 67 & 29.9 & 83 & 37.1 & 74 & 33.0 & \\
\hline Middle-aged/old adults & 107 & 60.8 & 54 & 30.7 & 15 & 8.5 & \\
\hline Residence area & & & & & & & 0.075 \\
\hline Rural & 74 & 40.4 & 73 & 39.9 & 36 & 19.7 & \\
\hline Urban & 100 & 46.3 & 64 & 29.2 & 53 & 24.5 & \\
\hline Marital status & & & & & & & $0.004^{*}$ \\
\hline Never married & 47 & 28.0 & 60 & 36.7 & 61 & 35.3 & \\
\hline Married & 127 & 54.7 & 77 & 33.2 & 28 & 12.1 & \\
\hline University level & & & & & & & $0.004^{*}$ \\
\hline No & 114 & 60.0 & 60 & 31.6 & 16 & 8.4 & \\
\hline Yes & 60 & 28.6 & 77 & 36.6 & 73 & 34.8 & \\
\hline Occupational status ${ }^{b}$ & & & & & & & $0.00 I^{*}$ \\
\hline Housewife & 81 & 57.4 & 50 & 35.5 & 10 & 7.1 & \\
\hline Other & 93 & 35.9 & 87 & 33.6 & 79 & 30.5 & \\
\hline Monthly total income & & & & & & & 0.428 \\
\hline$\leq 500 \$$ & 71 & 59.1 & 29 & 24.2 & 20 & 16.7 & \\
\hline$>500 \$$ & 103 & 36.8 & 108 & 38.6 & 69 & 24.6 & \\
\hline
\end{tabular}

aYoung adult: aged I8-39 years old; middle aged: $39-59$ years old; old adults: 60-74 years old.

'Occupational status: other means working women and students.

*Significance level set at $P<0.05$. 
respectively). Ninety-one percent of middle-aged and elder women, as well as the majority of young women $(67 \%)$ prepare themselves the hummus. There is no big difference between women from rural and urban areas. Income level also does not make a difference. The impact of academic level on hummus preparation is significantly important $(35 \%$ do not prepare hummus, $P$ $=0.004)$ in addition to the fact that women who work $(31 \%, P=0.001)$.

Proper hummus preparation among women

Table 10 presents the percentage of women considering proper preparation of chickpea and hummus, and its association with sociodemographic characteristics. Less than the quarter of the women consider all the steps of proper chickpea $(9.2 \%)$ and hummus preparation $(22.7 \%)$. Among the variables, the age was significantly related with considering proper preparation of hummus $(P<0.05)$ with the majority being older women $(66.5 \%)$.

\section{Discussion}

In the present survey, we aimed to assess iron intake, distinguish iron-rich dietary patterns and their association with nutrients intake and participant's sociodemographic characteristics, and investigate whether hummus is properly prepared among 400 Lebanese women from a nationally representative sample for age and region. The study was divided into two parts.

\section{Iron intake data}

In the first part, we assessed the nutritional intake deficiencies related to anemia and iron intake adequacy to the recommendations among the Lebanese women and its relation with the participants' characteristics. In addition, we investigated the consumption frequency of the main dietary sources of iron and the modifiers of iron bioavailability around mealtime. Moreover, we identified the iron-rich dietary patterns and their association with nutrients intake and participant's sociodemographic characteristics.

Table 10. Percentage of women considering proper preparation of chickpea and hummus, and its association with sociodemographic characteristics using the $\chi^{2}$ test $(n=174)$

\begin{tabular}{|c|c|c|c|c|c|c|c|c|c|c|}
\hline & \multicolumn{10}{|c|}{ Women considering preparation with each number of proper steps } \\
\hline & \multicolumn{5}{|c|}{ Chickpea, ${ }^{a} n(\%)$} & \multicolumn{5}{|c|}{ Hummus, $n(\%)$} \\
\hline & 0 & I & 2 & 3 & $P$ & 0 & I & 2 & 3 & $P$ \\
\hline Characteristics & $4(2.3)$ & $88(50.6)$ & $66(37.9)$ & $16(9.2)$ & & $16(9.3)$ & $54(31.4)$ & $63(36.6)$ & $39(22.7)$ & \\
\hline Age group ${ }^{c}$ & & & & & 0.36 & & & & & $0.00 *$ \\
\hline Young adult & $3(1.7)$ & $36(20.7)$ & $23(13.2)$ & $5(2.9)$ & & II (6.4) & $26(15.1)$ & $15(8.7)$ & $13(7.6)$ & \\
\hline Middle-aged/old adults & I (0.6) & $52(29.9)$ & $43(24.7)$ & II (6.3) & & $5(2.9)$ & $28(16.3)$ & 48 (27.9) & $26(15.1)$ & \\
\hline Residence area & & & & & 0.76 & & & & & 0.65 \\
\hline Rural & $2(1.1)$ & $37(21.3)$ & $30(17.2)$ & $5(2.9)$ & & $6(3.5)$ & $21(12.2)$ & $31(18.0)$ & $16(9.3)$ & \\
\hline Urban & $2(1.1)$ & $51(29.3)$ & $36(20.7)$ & II (6.3) & & $10(5.8)$ & $33(19.2)$ & $32(18.6)$ & $23(13.4)$ & \\
\hline Marital status & & & & & 0.34 & & & & & 0.11 \\
\hline Never married & $0(0.0)$ & $28(16.1)$ & $16(9.2)$ & $3(1.7)$ & & $8(4.7)$ & I5 (8.7) & $14(8.1)$ & $8(4.7)$ & \\
\hline Married & $4(2.3)$ & $60(34.5)$ & $50(28.7)$ & $13(7.5)$ & & $8(4.7)$ & $39(22.7)$ & $49(28.5)$ & $31(18.0)$ & \\
\hline University level & & & & & 0.38 & & & & & 0.31 \\
\hline No & I (0.6) & $59(33.9)$ & $43(24.7)$ & II (6.3) & & II (6.4) & $32(18.6)$ & $47(27.3)$ & $24(14.0)$ & \\
\hline Yes & $3(1.7)$ & $29(16.7)$ & $23(13.2)$ & $5(2.9)$ & & $5(2.9)$ & $22(12.8)$ & $16(9.3)$ & $15(8.7)$ & \\
\hline Occupational status ${ }^{d}$ & & & & & 0.49 & & & & & 0.59 \\
\hline Housewife & I (0.6) & $45(25.9)$ & 27 (I5.5) & $8(4.6)$ & & $7(4.1)$ & $23(13.4)$ & $34(19.8)$ & $17(9.9)$ & \\
\hline Other & $3(1.7)$ & $43(24.7)$ & $39(22.4)$ & $8(4.6)$ & & $9(5.2)$ & $31(18.0)$ & $29(16.9)$ & $22(12.8)$ & \\
\hline Monthly total income & & & & & 0.85 & & & & & 0.19 \\
\hline$\leq 500 \$$ & I (0.6) & $35(20.1)$ & $29(16.7)$ & $6(3.4)$ & & $7(4.1)$ & $16(9.3)$ & $31(18.0)$ & $17(9.9)$ & \\
\hline$>500 \$$ & $3(1.7)$ & $53(30.5)$ & $37(2 \mid .3)$ & $10(5.7)$ & & $9(5.2)$ & $38(22.1)$ & $32(18.6)$ & $22(12.8)$ & \\
\hline
\end{tabular}

aThree proper steps for chickpea preparation are soaking, pressure cooking, decortication (0: none of the steps; I: one of the three steps; 2: two of the three steps; 3 : all the three steps are considered).

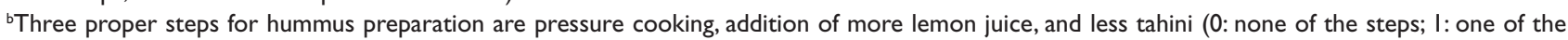
three steps; 2: two of the three steps; 3: all the three steps are considered).

'Young adult: aged I 8-39 years old; middle aged: $39-59$ years old; old adults: 60-74 years old.

'Occupational status: other means working women and students.

*Significance level set at $\mathrm{P}<0.05$. 


\section{Anemia-related nutritional intake deficiencies}

According to the WHO, the most important nutritional deficiencies causing anemia after iron deficiency are folate, vitamin B12, and vitamin A (48). Our study has shown that the percentage of childbearing-aged women having anemia-related nutritional intake deficiencies for iron $(59 \%)$, folate $(71 \%)$, and vitamin A $(82 \%)$ did not improve compared with previously reported results among Lebanese women $(3,49)$.

\section{Iron intake inadequacy among Lebanese women}

Our study shows an inadequate intake of iron $(65.6 \%$ of RDA) among reproductive-aged women (Table 3 ). This result is similar to previous national studies $(3,4,50)$ and could reveal a lack of awareness, among young women, about the increased body needs for iron during the reproductive age period and the necessity to increase dietary intake of iron. Comparing with other Mediterranean countries, our result ( $65.6 \%$ of RDA) is similar to Jordan (51) and Spain (52), slightly higher than Egypt (57\% of RDA) (53) and Greece (60\% of RDA) (54), but lower than Portugal (83.3\% of RDA), Italy (77.8\% of RDA) (55), Croatia (88.9\% of RDA) (56), and France (72\% of RDA) (57). As seen, women in Lebanon like in other developing countries have lower iron adequacy to RDA values than developed countries. This could be explained by several factors such as the absence of food fortification strategies that increase iron content in staple food, the lack of awareness programs about the need to increase iron intake levels in the reproductive age period of the women, and the relatively lower socioeconomic status leading to less food diversity which contributes to better nutritional iron intake (58).

\section{Iron intake and sociodemographic characteristics}

The monthly income sociodemographic factor was shown to have a significant correlation with total iron intake, iron intake adequacy, and iron intake deficiency (Tables 4 and 5). This could be explained by the fact that household with lower income has been consistently associated with poorer quality of dietary intake (59). Older women were shown to have better iron adequacy and were less likely to have iron intake deficiency as the recommended dietary intake for iron for postmenopausal women is less than twice the recommended amount for premenopausal women, who have increased body needs for iron. Holding a higher university degree was positively associated with total iron intake as individuals with a higher educational level were shown in previous studies to have higher-quality diets than their counterparts (60).

\section{Main sources of dietary iron}

Our results show that the major sources of heme iron are beef and chicken, as reported by a previous Lebanese study (61). Nonheme iron is significantly more frequently consumed than heme iron, and its main sources reported were green leafy vegetables, legumes, and hummus. Legumes and hummus are not only good sources of iron but also complementary to meat. Our results indicate that the frequency of legumes consumption (3-6 times/week) is satisfactory to the dietary guidelines for middle eastern countries (62). Moreover, our results are similar to previously reported studies in Jordan (63) and Greece (64), where legume consumption was shown to be 3-4 times per week, and more frequent than other Mediterranean countries such as Spain and Italy (once per week) $(65,66)$. This signifies a preservation of legume consumption in Lebanon although the concomitant tendency to shift to more westernized diets (42). Hummus is frequently consumed (at least once/week) by the interviewed women. In the Middle Eastern countries, more than $75 \%$ of chickpea are consumed as hummus and falafel (fried chickpea patties) $(67,68)$.

\section{Modifiers of iron bioavailability around mealtimes}

According to Asmar et al. (4), consumption of tea/coffee and soft drinks among women was predictors of iron deficiency and anemia. Therefore, we have asked the women of their consumption of enhancers and inhibitors of iron bioavailability around mealtime. The frequency of consumption was higher for inhibitors around meal times than enhancers. This is supported by other studies in Lebanon (4) and other developed countries such as Brazil (69) and Australia (70). This could reveal a lacking in dietary knowledge about the consumption of iron enhancers and inhibitors around mealtimes, in both developing and developed countries.

\section{Iron-rich dietary patterns}

Among the four iron-rich dietary patterns obtained, legumes, organ/lunch meat chicken, canned fish, and beef and hummus, the association between beef and hummus was of interest to discuss since beef is an iron bioavailability enhancer $(71,72)$. The reason for their association is that hummus is eaten as a mezza and accompanies beef consumption. This was confirmed by our study as the majority of the women revealed the preference of meat consumption with hummus (Fig. 1).

\section{Iron-rich dietary patterns and nutrients intake}

Although hummus does not contain heme iron, its association with the beef in the same dietary pattern assigned it with a higher heme iron intake. The higher ascorbic acid associated could be due to the content of lemon juice in hummus and the accompanied consumption of ascorbic-acid-rich vegetables with hummus, as shown in our study (Fig. 1). The association with vitamin B12 and folate is due to their high content in beef $(73,74)$. These 
results are in accordance with Wallace et al. (14), showing that consumers of hummus had higher dietary intakes of vitamin $\mathrm{A}$, vitamin $\mathrm{C}$, folate, and iron as compared with nonconsumers (14).

Iron-rich dietary patterns and population characteristics Lower household income was the only sociodemographic variable that predicted the canned fish-based dietary pattern. This is consistent with a previous study, showing that low-income households have higher consumption of canned fish compared with higher-income households that consume rather fresh food $(75,76)$.

\section{Hummus preparation and consumption}

In the second part, women who prepare hummus traditionally were identified, and they were assessed for whether or not they considered preparing chickpea and hummus properly for an enhanced iron bioavailability.

\section{Women who still prepare hummus traditionally}

Detailed information about the women who prepare hummus traditionally is provided. Our results showing the older, married women, housewives, and women with low academic level who prepare mainly hummus are explained and comparable with other studies. According to Moisio et al. (77), food preparation is perceived as a duty and not as a self-accomplishment among senior women (77). Moreover, other studies have shown food preparation as a responsibility of the married women and housewives toward their families $(78,79)$. On the contrary, working women as well as women with higher academic level did not have enough time prepare to food $(80,81)$.

\section{Proper preparation of chickpea and hummus among} the women

Finally, we have investigated if the women take into consideration the steps that have been proven by literature to improve iron bioavailability from chickpea as well as hummus. As only 22.7 and $9.2 \%$ of the women reported to consider proper preparation of chickpea and hummus, respectively, this implies that the proper preparation steps of plant-based food are not well taken into account. The reason must be primarily a lack of awareness. Older women were shown to prepare hummus more properly than younger women. We believe that the reason is not related to improve iron bioavailability rather, to some culinary hacks acquired with the experience. For example, some would soak chickpea in baking soda and decorticate it as these two culinary techniques give a better texture of hummus and decrease the factors causing flatulence (82). Others would prefer pressure cooking over boiling as it reduces the cooking time of chickpea (83).

\section{Hummus consumption}

As for hummus combination with food and beverage, our findings report its consumption with more inhibitors (pita bread and soft drinks) than enhancers (meat), as it is the case for the higher frequency of inhibitors consumption with general food. Pita bread cannot be avoided in the Lebanese diet as it is usually consumed with all the meals (50). It is, however, better than whole wheat bread intake when iron bioavailability is in priority of consideration as it is less rich in phytate than the unrefined bread $(84,46)$. Therefore, hummus, like other legumes and iron-containing plant foods, must be consumed with a vitamin C-rich food source, or with at least small quantities of meat, chicken, or fish for a better iron bioavailability (37).

\section{Strength and limitations of the study}

Our study has certain strength points as well as limitations. This is the first study that identify the iron-rich dietary patterns among the Lebanese women and that assess their consideration of the proper preparation of chickpea and hummus for a better iron bioavailability. The limitations include the execution of a single 24-h recall considering the limited time provided for the study and the lack of financial support that would allow to run blood test analysis and assess iron deficiency, iron deficiency anemia, and anemia among the women in our sample.

\section{Conclusion}

In summary, the present study provides updated data about the nutritional intake of iron and other anemia-related nutrients among women from all Lebanese regions. It reveals that the dietary intake of iron among reproductive age women is still inadequate with about $60 \%$ of the women having iron intake deficiency with the women with lower income being the most affected. It is the first study showing the presence of four distinct iron-rich dietary patterns among the Lebanese women, with hummus-related pattern being the only one associated positively with protein, ascorbic acid, iron, folate, vitamin B12, and vitamin A intake. Moreover, it is the first to investigate whether women consider proper preparation of chickpea and hummus to improve iron bioavailability. The consumption of iron inhibitors around mealtime and hummus is frequent. Intervention programs spreading awareness among Lebanese women are needed for encouraging adequate iron intake, as well as the consumption of iron bioavailability enhancers more frequently than inhibitors around mealtimes, and finally, considering proper food preparation steps to improve iron bioavailability from plant-based food.

\section{Acknowledgments}

The authors express deepest appreciation to the study participants. The authors also gratefully acknowledge the support 
of the Lebanese University, Azm \& Saade Association, and the Regional Council of Bourgogne Franche-Comté, 'Fonds Européen de Développement Regional' (FEDER).

\section{Conflict of interest and funding}

The authors declare no potential conflicts of interest.

\section{References}

1. Petry N, Olofin I, Hurrell R, Boy E, Wirth J, Moursi M, et al. The Proportion of Anemia Associated with Iron Deficiency in Low, Medium, and High Human Development Index Countries: A Systematic Analysis of National Surveys. Nutrients 2016 Nov; 8(11):693-709. doi: 10.3390/nu8110693

2. McLean E, Cogswell M, Egli I, Wojdyla D, de Benoist B. Worldwide prevalence of anaemia, WHO Vitamin and Mineral Nutrition Information System, 1993-2005. Public Health Nutr 2009 Apr; 12(04): 444. doi: 10.1017/S1368980008002401

3. Khatib LA, Obeid O, Sibai A-M, Batal M, Adra N, Hwalla N. Folate deficiency is associated with nutritional anaemia in Lebanese women of childbearing age. Public Health Nutr 2006; 9(07):921-927. doi: 10.1017/PHN2005921

4. Asmar MK, Zablit CG, Daou R, Yéretzian JS, Daoud H, Rady A, et al. Prevalence of anemia and associated factors in women of childbearing age in rural Lebanon. J Public Health 2018 Feb; 26(1): 39-49. doi: 10.1007/s10389-017-0853-9

5. Hunt JR. Bioavailability of iron, zinc, and other trace minerals from vegetarian diets. Am J Clin Nutr 2003 Sep 1; 78(3): 633S-9S. doi: 10.1093/ajen/78.3.633S

6. Gerber PJ, Vellinga TV, Steinfeld H. Issues and options in addressing the environmental consequences of livestock sector's growth. Meat Sci 2010 Feb; 84(2): 244-7. doi: 10.1016/j. meatsci.2009.10.016

7. Leip A, Billen G, Garnier J, Grizzetti B, Lassaletta L, Reis S, et al. Impacts of European livestock production: nitrogen, sulphur, phosphorus and greenhouse gas emissions, land-use, water eutrophication and biodiversity. Environ Res Lett 2015 Nov 1; 10(11): 115004. doi: 10.1088/1748-9326/10/11/115004

8. Wolk A. Potential health hazards of eating red meat. J Intern Med [Internet] 2017 Feb; 281(2): 106-22. Available from: http:// doi.wiley.com/10.1111/joim.12543 [cited 19 December 2019].

9. Kim SJ, de Souza RJ, Choo VL, Ha V, Cozma AI, Chiavaroli L, et al. Effects of dietary pulse consumption on body weight: a systematic review and meta-analysis of randomized controlled trials. Am J Clin Nutr 2016 May; 103(5): 1213-23. doi: 10.3945/ ajen.115.124677

10. Satija A, Hu FB. Plant-based diets and cardiovascular health. Trends Cardiovasc Med 2018 Oct; 28(7): 437-41. doi: 10.1016/j. tcm.2018.02.004

11. Tuso P. Nutritional update for physicians: plant-based diets. Perm J 2013 Apr 22; 17(2): 61-6.

12. Wu A, Lesperance L, Bernstein H. Screening for iron deficiency. 2002. Available from: http://www.nccpeds.com/ContinuityModules-Fall/Faculty $\% 20$ Modules/Health\%20Maintenance $\% 20$ II-faculty.pdf [cited 26 September 2017].

13. Kenawi MA. Chemical composition, nutritional value, and in-vitro protein digestibility of three traditional breakfast foods in Jordan. Plant Foods Hum Nutr 2003; 58(3): 1-6. doi: 10.1023/B:QUAL.0000041177.65248.b4

14. Wallace T, Murray R, Zelman K. The nutritional value and health benefits of chickpeas and hummus. Nutrients $2016 \mathrm{Nov}$ 29; 8(12): 766. doi: 10.3390/nu8120766
15. Canadian [A3Q4]Nutrient File. Food sources of iron [Internet]. 2015. Available from: www.hc-sc.gc.ca/fn-an/nutrition/fiche-nutri-data/index-eng.php [cited 20 January 2020].

16. Gupta A. Iron metabolism in human body. In: Nutritional anemia in preschool children [Internet]. Singapore: Springer Singapore; 2017, pp. 29-46. Available from: http://link.springer. com/10.1007/978-981-10-5178-4_4 [cited 28 April 2018].

17. Davies CV, Gerard LM, Ferreyra MM, Schvab MdC, Solda CA. Bioactive compounds and antioxidant activity analysis during orange vinegar production. Food Sci Technol 2017 May 15; 37(3): 449-55. doi: 10.1590/1678-457x.20816

18. Haileslassie HA, Henry CJ, Tyler RT. Impact of household food processing strategies on antinutrient (phytate, tannin and polyphenol) contents of chickpeas ( Cicer arietinum L.) and beans (Phaseolus vulgaris L.): a review. Int J Food Sci Technol 2016 Sep; 51(9): 1947-57. doi: 10.1111/ijfs. 13166

19. Hefni M, M. Witthöft C. Enhancement of the folate content in Egyptian pita bread. Food Nutr Res [Internet] 2012 Jan; 56(1): 5566. Available from: http://foodandnutritionresearch.net/ index.php/fnr/article/view/499 [cited 26 January 2020].

20. Carvalho Lucia MJ, Corrêa Mariana M, Pereira Elenilda J, Nutti Marília R, Carvalho José LV, Ribeiro Ediane MG, et al. Iron and zinc retention in common beans (Phaseolus vulgaris L.) after home cooking. Food Nutr Res [Internet] 2012 Jan; 56(1): 15618. Available from: http://foodandnutritionresearch.net/index.php/fnr/article/view/487 [cited 26 January 2020].

21. Alajaji SA, El-Adawy TA. Nutritional composition of chickpea (Cicer arietinum $\mathrm{L}$.) as affected by microwave cooking and other traditional cooking methods. J Food Compos Anal [Internet] 2006 Dec; 19(8): 806-12. Available from: https://linkinghub.elsevier.com/retrieve/pii/S0889157506000561 [cited 19 December 2019].

22. El-Adawy TA. Nutritional composition and antinutritional factors of chickpeas (Cicer arietinum L.) undergoing different cooking methods and germination. Plant Foods Hum Nutr [Internet] 2002; 57(1): 83-97. Available from: http://link.springer. com/10.1023/A:1013189620528 [cited 19 December 2019].

23. Khandelwal S, Udipi SA, Ghugre P. Polyphenols and tannins in Indian pulses: effect of soaking, germination and pressure cooking. Food Res Int [Internet] 2010 Mar; 43(2): 526-30. Available from: https://linkinghub.elsevier.com/retrieve/pii/ S0963996909003019 [cited 19 December 2019].

24. Singh PK, Shrivastava N, Sharma B, Bhagyawant SS. Effect of domestic processes on chickpea seeds for antinutritional contents and their divergence. Am J Food Sci Technol 2015; 8:111117. doi: 10.12691/ajfst-3-4-3

25. Pereira EJ, Carvalho LMJ, Dellamora-Ortiz GM, Cardoso FSN, Carvalho JLV. Effect of different home-cooking methods on the bioaccessibility of zinc and iron in conventionally bred cowpea (Vigna unguiculata L. Walp) consumed in Brazil. Food Nutr Res [Internet] 2016 Jan; 60(1): 29082. Available from: http:// foodandnutritionresearch.net/index.php/fnr/article/view/1036 [cited 26 January 2020].

26. Ghavidel RA, Prakash J. The impact of germination and dehulling on nutrients, antinutrients, in vitro iron and calcium bioavailability and in vitro starch and protein digestibility of some legume seeds. LWT - Food Sci Technol [Internet] 2007 Sep; 40(7): 1292-9. Available from: https://linkinghub.elsevier.com/ retrieve/pii/S0023643806002209 [cited 19 December 2019].

27. Doumani N, Severin I, Dahbi L, Bou-Maroun E, Tueni M, Sok N, et al. Lemon juice, sesame paste, and autoclaving influence iron bioavailability of hummus: assessment by an in vitro 
digestion/caco-2 Cell Model. Foods [Internet] 2020 Apr 10; 9(4): 474. Available from: https://www.mdpi.com/2304-8158/9/4/474 [cited 14 April 2020].

28. Capuano E. The behavior of dietary fiber in the gastrointestinal tract determines its physiological effect. Crit Rev Food Sci Nutr 2017 Nov 2; 57(16): 3543-64. doi: 10.1080/10408398.2016.1180501

29. Raymond J, Kassim N, Rose JW, Agaba M. Optimal formulations of local foods to achieve nutritional adequacy for 6-23-month-old rural Tanzanian children. Food Nutr Res [Internet] 2017 Jan; 61(1): 1358035. Available from: http:// foodandnutritionresearch.net/index.php/fnr/article/view/1254 [cited 26 January 2020].

30. Lai-Yeung TWL. Hong Kong parents' perceptions of the transference of food preparation skills: parents' views of food preparation skills. Int J Consum Stud [Internet] 2015 Mar; 39(2): 117-24. Available from: http://doi.wiley.com/10.1111/ijcs. 12158 [cited 23 January 2020].

31. Sidani YM, Al Hakim ZT. Work-family conflicts and job attitudes of single women: a developing country perspective. Int $\mathrm{J}$ Hum Resour Manag [Internet] 2012 Apr; 23(7): 1376-93. Available from: http://www.tandfonline.com/doi/abs/10.1080/095851 92.2011.579919 [cited 19 December 2019].

32. Tlaiss HA, Dirani KM. Women and training: an empirical investigation in the Arab Middle East. Hum Resour Dev Int [Internet] 2015 Jun 11; 1-21. Available from: http://www.tandfonline.com/doi/full/10.1080/13678868.2015.1050315 [cited 19 December 2019].

33. CAS-Regions. Central Administration of Statistics in 2009 [Internet]. Population, population characteristics, Excel tables, RES. 5. 2009. Available from: http://www.cas.gov.lb/index.php/ demographic-and-social-en [cited 1 January 2020].

34. Yamane T. Statistics, an introductory analysis. 2nd ed. New York: Harper and Row; 1967.

35. WHO. World Health Organization, Global Health Observatory (GHO) data Mean Body Mass Index (BMI) [Internet]. 2019. Available from: https://www.who.int/gho/ncd/risk_factors/bmi_ text/en/ [cited 19 October 2019].

36. Institute of Medicine. Dietary reference intakes for energy, carbohydrate, fiber, fat, fatty acids, cholesterol, protein, and amino acids. Washington, DC: The National Academies Press; 2005.

37. Hwalla N, Nasreddine L, Farhat Jarrar S. The food-based dietary guideline manual for promoting healthy eating in the Lebanese adult population. Beirut, Lebanon: The Faculty of Agricultural and Food Sciences, American University of Beirut; 2013.

38. Nutrilog. Nutrition Software for Professionals [Internet]. Marans, France: Nutrilog SAS; 2018. Available from: https://nutrilog.com/Nutrilog_en/ index.htm [cited 20 January 2020].

39. Pellet PL, Shadarevian S. Food composition tables for use in the Middle East Beirut. 2nd ed. American University of Beirut, Lebanon: Division of Food Technology and Nutrition, Faculty of Agricultural Science; 1970.

40. USDA. U.S. Department of Agriculture, Agricultural Research Service, USDA Nutrient Data Laboratory, Beirut, Lebanon: FoodData Central [Internet]. 2004. Available from: https://fdc. nal.usda.gov/ [cited 1 January 2020].

41. Michels KB, Schulze MB. Can dietary patterns help us detect diet-disease associations? Nutr Res Rev [Internet] 2005 Dec; 18(2): 241-8. Available from: https://www.cambridge.org/core/ product/identifier/S0954422405000181/type/journal_article [cited 22 June 2020].
42. Naja F, Nasreddine L, Itani L, Chamieh MC, Adra N, Sibai AM, et al. Dietary patterns and their association with obesity and sociodemographic factors in a national sample of Lebanese adults. Public Health Nutr [Internet] 2011 Sep; 14(9): 1570-8. Available from: https://www.cambridge.org/core/product/identifier/S136898001100070X/type/journal_article [cited 20 December 2019].

43. Skolmowska D, Głąbska D. Analysis of Heme and NonHeme Iron Intake and Iron Dietary Sources in Adolescent Menstruating Females in a National Polish Sample. Nutrients. 2019 May 10;11(5):1049. doi: 10.3390/nu11051049

44. Willett WC, Howe GR, Kushi LH. Adjustment for total energy intake in epidemiologic studies. Am J Clin Nutr [Internet] 1997 Apr 1; 65(4): 1220S-8S. Available from: https://academic.oup.com/ajcn/article/65/4/1220S/4655744 [cited 25 June 2020].

45. DRI. Dietary reference intakes for vitamin A, vitamin K, arsenic, boron, chromium, copper, iodine, iron, manganese, molybdenum, nickel, silicon, vanadium, and zinc. Washington, DC: National Academy Press. Food and Nutrition Board (FNB), Institute of 524 Medicine (IOM); 2002.

46. Harland BF, Harland J. Fermentative reduction of phytate in rye, white, and whole wheat breads. Cereal Chemistry Journal [Internet] 1980; 57(3): 226-9. Available from: http://agris.fao. org/agris-search/search.do?recordID=US19810693126 [cited 27 July 2020].

47. Kamal S, Othman S. Expanded alphabet of cooking. Beirut: Dar El-Ilm Lilmalayin; 2015.

48. WHO. World Health Organization, anaemia, overview [Internet]. 2020. Available from: https://www.who.int/health-topics/ anaemia\#tab=tab_1 [cited 12 August 2020].

49. Jomaa L, Naja F, Cheaib R, Hwalla N. Household food insecurity is associated with a higher burden of obesity and risk of dietary inadequacies among mothers in Beirut, Lebanon. BMC Public Health [Internet] 2017 Dec; 17(1): 567. Available from: http://bmcpublichealth.biomedcentral. com/articles/10.1186/s12889-017-4317-5 [cited 13 August 2020].

50. Hwalla N, Adra N, Jackson RT. Iron deficiency is an important contributor to anemia among reproductive age women in Lebanon. Ecol Food Nutr [Internet] 2004 Jan; 43(1-2): 77-92. Available from: http://www.tandfonline.com/doi/ abs/10.1080/03670240490274101 [cited 23 January 2020].

51. Tayyem RF, Abu-Mweis SS, Bawadi HA, Agraib L, Bani-Hani $\mathrm{K}$. Validation of a food frequency questionnaire to assess macronutrient and micronutrient intake among Jordanians. J Acad Nutr Diet 2014 Jul; 114(7): 1046-52. doi: 10.1016/j. jand.2013.08.019

52. Serra-Majem L, Ribas-Barba L, Salvador G, Jover L, Raidó B, Ngo J, et al. Trends in energy and nutrient intake and risk of inadequate intakes in Catalonia, Spain (1992-2003). Public Health Nutr [Internet] 2007 Nov; 10(11A). Available from: http://www. journals.cambridge.org/abstract_S1368980007000961 [cited 24 November 2019].

53. Youssef MM, Mohsen MA, El-Soud NHA, Kazem YA. Energy intake, diet composition among low social class overweight and obese Egyptian adolescents. 2010; 9. Available from: https:// pdfs.semanticscholar.org/37db/0b56224fbb6e014d4f4e1946bcc4e8832def.pdf [cited 4 August 2020].

54. Klimis-Zacas DJ, Kalea AZ, Yannakoulia M, Matalas A-L, Vassilakou T, Papoutsakis-Tsarouhas C, et al. Dietary intakes of Greek urban adolescents do not meet the recommendations. Nutr Res 2007 Jan; 27(1): 18-26. doi: 10.1016/j.nutres.2006.12.004 
55. Elmadfa I, editor. European nutrition and health report 2009. Basel, Switzerland; New York: Karger; 2009, 412 p. (Forum of nutrition).

56. Šatalić Z, Colić Barić I, Keser I. Diet quality in Croatian university students: energy, macronutrient and micronutrient intakes according to gender. Int J Food Sci Nutr 2007 Jan; 58(5): 398-410. doi: 10.1080/09637480701252393

57. AFSSA. Étude indivuduelle nationale des consommations alimentaires 2 (INCA-2) 2006-2007 [Internet]. 2009, p. 225. Available from: https://www.anses.fr/fr/system/files/PASER-RaINCA2.pdf [cited 22 November 2019].

58. Marangoni F, Corsello G, Cricelli C, Ferrara N, Ghiselli A, Lucchin L, et al. Role of poultry meat in a balanced diet aimed at maintaining health and wellbeing: an Italian consensus document. Food Nutr Res [Internet] 2015 Jan; 59(1): 27606. Available from: http://foodandnutritionresearch.net/index.php/fnr/article/ view/758 [cited 26 January 2020].

59. French SA, Tangney CC, Crane MM, Wang Y, Appelhans BM. Nutrition quality of food purchases varies by household income: the SHoPPER study. BMC Public Health [Internet] 2019 Dec; 19(1): 231. Available from: https://bmcpublichealth. biomedcentral.com/articles/10.1186/s12889-019-6546-2 [cited 8 August 2020].

60. Marques-Vidal P, Rousi E, Paccaud F, Gaspoz J-M, Theler $\mathrm{J}-\mathrm{M}$, Bochud $\mathrm{M}$, et al. Dietary intake according to gender and education: a twenty-year trend in a Swiss adult population. Nutrients [Internet] 2015 Nov 18; 7(11): 9558-72. Available from: http://www.mdpi.com/2072-6643/7/11/5481 [cited 9 August 2020].

61. Nasreddine L, Hwalla N, Sibai A, Hamzé M, Parent-Massin D. Food consumption patterns in an adult urban population in Beirut, Lebanon. Public Health Nutr [Internet] 2006 Apr; 9(02). Available from: http://www.journals.cambridge.org/abstract_ S1368980006000383 [cited 23 July 2018].

62. Montagnese C, Santarpia L, Iavarone F, Strangio F, Sangiovanni B, Buonifacio M, et al. Food-based dietary guidelines around the world: Eastern Mediterranean and Middle Eastern Countries. Nutrients 2019 Jun 13; 11(6): 1325. doi: 10.3390/ nu11061325

63. Musaiger AO, Hammad SS, Tayyem RF, Qatatsheh AA. Socio-demographic and dietary factors associated with obesity among female university students in Jordan. Int J Adolesc Med Health 2015; 27:299-305. doi: 10.1515/ijamh-2014-0029

64. Papavagelis C, Avgeraki E, Augoulea A, Stamatelopoulos K, Lambrinoudaki I, Yannakoulia M. Dietary patterns, Mediterranean diet and obesity in postmenopausal women. Maturitas 2018 Apr; 110: 79-85. doi: 10.1016/j.maturitas.2018.02.001

65. de la Fuente-Arrillaga C, Zazpe I, Santiago S, Bes-Rastrollo M, Ruiz-Canela M, Gea A, et al. Beneficial changes in food consumption and nutrient intake after 10 years of follow-up in a Mediterranean cohort: the SUN project. BMC Public Health 2016 Dec; 16(1): 203. doi: 10.1186/ s12889-016-2739-0

66. Fiore M. Legumes consumption among young and adult residents in sicily (South Italy): evidence and predictive factors. J Nutr Health Food Sci 2017 Feb 27; 5(1): 1-4. doi: 10.15226/ jnhfs. 2017.00188

67. Tayyem RF, Bawadi HA, Salameh MA. Dietary and physical activity profiles of a sample of college students in Jordan. Jordan J Agric Sci 2008; 4: 13. Available from: https://www.researchgate. net/publication/228344352_Dietary_and_Physical_Activity_580
Profiles_of_a_Sample_of_College_Students_in_Jordan [cited 20 January 2020].

68. Yadav SS, editor. Chickpea breeding and management. Wallingford, UK; Cambridge, MA: CABI; 2007, 638 p.

69. Sato APS, Fujimori E, Szarfarc SC, Borges ALV, Tsunechiro MA. Food consumption and iron intake of pregnant and peproductive aged women. Rev Lat Am Enfermagem 2010 Apr; 18(2): 247-54. doi: 10.1590/S0104-11692010000200016

70. Leonard AJ, Chalmers KA, Collins CE, Patterson AJ. The effect of nutrition knowledge and dietary iron intake on iron status in young women. Appetite 2014 Oct; 81: 225-31. doi: 10.1016/j. appet.2014.06.021

71. Kapsokefalou M, Miller DD. Effects of meat and selected food components on the valence of nonheme iron during in vitro digestion. J Food Sci [Internet] 1991 Mar; 56(2): 352-5. Available from: http://doi.wiley.com/10.1111/j.1365-2621.1991.tb05278.x [cited 19 December 2019].

72. Gangloff MB, Glahn RP, Miller DD, Van Campen DR. Assessment of iron availability using combined in vitro digestion and Caco-2 cell culture. Nutr Res [Internet] 1996 Mar; 16(3): 479-87. Available from: https://linkinghub.elsevier.com/retrieve/ pii/0271531796000292 [cited 19 Dec 2019].

73. Bennink MR, Ono K. Vitamin B12, E and D content of raw and cooked beef. J Food Sci [Internet] 1982 Nov; 47(6): 1786-92. Available from: http://doi.wiley.com/10.1111/j.1365-2621.1982. tb12883.x [cited 9 August 2020].

74. Aiso K, Tamura T. Trienzyme treatment for food folate analysis: optimal $\mathrm{pH}$ and incubation time for alpha-amylase and protease treatments. J Nutr Sci Vitaminol (Tokyo) [Internet] 1998; 44(3): 361-70. Available from: http://joi.jlc.jst.go.jp/ JST.Journalarchive/jnsv1973/44.361?from $=$ CrossRef [cited 9 August 2020].

75. Powers B. Differences in food store environment in low-income Grand Rapids neighborhoods composed of different ethnicities. Honors Projects 2018. 693: 12. Available from: https://scholarworks.gvsu.edu/honorsprojects [cited 4 August 2020].

76. Darmon N, Drewnowski A. Does social class predict diet quality? Am J Clin Nutr [Internet] 2008 May 1; 87(5): 1107-17. Available from: https://academic.oup.com/ajcn/article/87/5/1107/4650128 [cited 9 August 2020].

77. Moisio R, Arnould EJ, Price LL. Between mothers and markets: constructing family identity through homemade food. J Consum Cult [Internet] 2004 Nov; 4(3): 361-84. Available from: http://journals.sagepub.com/doi/10.1177/1469540504046523 [cited 19 December 2019].

78. Hassan HF, Dimassi H. Food safety and handling knowledge and practices of Lebanese university students. Food Control [Internet] 2014 Jun; 40: 127-33. Available from: https://linkinghub.elsevier.com/retrieve/pii/S0956713513006221 [cited 23 January 2020].

79. Dumit NY, Noureddine SN, Magilvy JK. Perspectives on barriers and facilitators to self-care in Lebanese cardiac patients: a qualitative descriptive study. Int J Nurs Stud [Internet] 2016 Aug; 60: 69-78. Available from: https:// linkinghub.elsevier.com/retrieve/pii/S0020748916300013 [cited 19 December 2019].

80. Sharif MSMd, Nor NM, Zahari MSM, Muhammad R. What makes the malay young generation had limited skills and knowledge in the malay traditional food preparation? Procedia - Soc Behav Sci [Internet] 2015 Aug; 202: 152-8. Available from: 
https://linkinghub.elsevier.com/retrieve/pii/S1877042815048661 [cited 19 December 2019].

81. Tlaiss H, Kauser S. The impact of gender, family, and work on the career advancement of Lebanese women managers. Gend Manag Int J [Internet] 2011 Feb 15; 26(1): 8-36. Available from: https://www.emerald.com/insight/content/ doi/10.1108/17542411111109291/full/html [cited 19 Dec 2019].

82. Jawad Y. Best Lebanese hummus recipe [Internet]. Feel Good Foodie 2019. Available from: https://feelgoodfoodie.net/recipe/ best-hummus/ [cited 20 January 2020].

83. Güzel D, Sayar S. Effect of cooking methods on selected physicochemical and nutritional properties of barlotto bean, chickpea, faba bean, and white kidney bean. J Food Sci Technol [Internet] 2012 Feb; 49(1): 89-95. Available from: http:// link.springer.com/10.1007/s13197-011-0260-0 [cited 8 Aug 2020].
84. Eagling T, Wawer AA, Shewry PR, Zhao F-J, Fairweather-Tait SJ. Iron bioavailability in two commercial cultivars of wheat: comparison between wholegrain and white flour and the effects of nicotianamine and 2'-deoxymugineic acid on iron uptake into caco-2 cells. J Agric Food Chem 2014 Oct 22; 62(42): 10320-5. doi: $10.1021 /$ jf5026295

\section{*Nour Doumani}

Department of Biology

Nutrition \& Dietetics, Faculty of Sciences II

Lebanese University

90656 Jdeideth El Matn

Fanar

Beirut, Lebanon

Email: nour.doumani@agrosupdijon.fr; nourdoumani@live.com 